\title{
Knowledge partnerships for SDG 4: Bridge 7 and GCE in perspective
}

Talia Vela-Eiden and Silvana Longueira Matos

European Association of Development Research and Training Institutes/Bridge 47-Building Global Citizenship and Universidade de Santiago de Compostela, Germany and Spain

DOI: http://dx.doi.org/10.15304/ricd.3.13.7271

\section{NOTAS BIOGRÁFICAS}

Talia Vela-Eiden is a Knowledge Exchange Partnerships Officer, EADI - European Association of Development Research and Training Institutes and Bridge 47-Building Global Citizenship. She is a member of the Partnerships Team and coordinates the Knowl edge Exchange Partnerships.

Contacto: talia.vela-eiden@bridge47.org

Silvana Longueira Matos is a professor in the area of Theory and History of Education at the Universidade de Santiago de Compostela, as well as a member of the Research Group Terceira Xeración (TeXe). She is the Coordinator of the Sustainable Development Plan at the USC and also a member of the Education for Development Working Group of the Cooperation Council. As well, she is a member of the OCUD Advisory Council and the Galician Council for Development Cooperati on, the Coordinator of the Curricular 'Sustainable-isation' Working Group at CRUE-Sostenibilidad.

Contacto: silvana.longueira@usc.es

\section{Abstract}

With the start of the decade of action and results for development, Sustainable Development Goal 4 (SDG 4) continues to show the impossibility of its achievement in 2030. Within this framework, we have asked ourselves about the major challenges facing education by using a concrete example, the Bridge 47-Building Global Citizenship project, which allows us to ask ourselves about the creation of shared spaces among organised civil society, academia, professionals and political decisionmakers to defend and associate in favour of Education for Global Citizenship (EGC) and transformative change in society.

Bridge 47-Building Global Citizenship mobilises global civil society to contribute to global justice and eradication of poverty through Global Citizenship Education (GCE) and advocating for target 4.7 of the Sustainable Development Goals (SDGs), which is related to education for social transformation.

The results of Bridge 47 are focused on generating learning and exchange opportunities between experts to share their research and projects, inspiring people to act and providing a roadmap to administrations for the development of SDG4 target 4.7. "Quality education".

\section{Keywords}

Education for Global Citizenship (ECG), Sustainable Development Goals (SDG), Target 4.7, Citizen participation; Global Civil Society. 


\section{Contents}

1. Introduction

2. SDG 4: Quality Education

3. Global Citizenship Education (GCE)

4. The role of european CSO in expanding the concept of GCE

5. The Bridge 47 Project. GCE as the main focus in Europe

6. Knowledge exchange partnerships for bridging CSOs and HE

7.Bridge's work methodology

8. Conclusions 


\section{INTRODUCTION}

Having consumed a third of the estimated time for the fulfilment of the Sustainable Development Goals, we have not been able to articulate deep changes in paradigms of thinking and action that could bring us closer to valid responses to the major global challenges. This is the reason that has motivated the approval of the decade of action and results in favour of sustainable development (UN, 2019).

In this framework, SDG 4 becomes even more necessary and urgent, due to the particular implications of its goals, but also because of its cross-cutting nature with respect to other global challenges. This leads us to believe that it is useful to know how the fulfilment of goal 4.7 is being addressed on the basis of a European project involving organised civil society, academia and political decision-makers, as a descripttion of the process that will help to shed light on the education we need for the challenges we urgently face.

The Bridge 47 project aims to activate civil society, social fabric and collective knowledge building, facilitating dialogue between society and the academic environment - with this as one of its strengths -, the confluence of different social actors concerning the Sustainable Development Goal 4 (SDG4) and quality education.

The European Association of Development Research and Training Institutes (EADI), is a member of the Bridge 47 consortium and it takes the leading role in the work on Knowledge Exchange Partnerships in Europe promoting a flow of information and best practices between higher education institutions and civil society organisations. This is done by building new and strengthening existing regional partnerships, through activities, networking, and joint initiateves, bridging the gaps between higher education and civil society organisations. The Knowledge Exchange Partnerships in Iberia, Northern Europe, and South-Eastern Europe are open to all interested participants.

In light of the reduction of participation spaces, the infodemic and the extent of political and social positioning regarding freedom and heterogeneous discourses, Bridge 47 draws from Global Citizenship Education (GCE) as a tool for change, transformation and building a common future that answers major global challenges.

The project is particularly appropriate as it can extend the intervention through GCE from its three distinctive approaches. Three different narratives about GCE are made compatible to create a better capacity for communication, understanding and rapprochement that seek to deliver solutions and arguments for GCE in ways that do not underestimate the complexity of global challenges ahead of us and that also attempt to create space for more critical and non-mainstream approaches.

The results of the project can be gathered in three key lines that focus on providing resources for GCE work and training and the progress of Target 4.7, on creating collaborative networks and knowledge and on advocacy. The European Commission's political priorities until 2024 are used as a reference.

The focus is on transformative education as life-long and value-based learning, designed to promote global citizenship, sustainable development, human rights and gender equality.

\section{SDG 4: QUALITY EDUCATION}

In the year 2015, the Sustainable Development Goals (SDGs) were adopted at a historic United Nations summit. SDG 4 is linked to ensuring inclusive, equitable and quality education and promoting lifelong learning opportunities for all. Furthemore, education is present in a transversal way in the other SDGs, as, in addition to being an end, it is considered as a means or tool to enable the fulfilment of 2030 Agenda.

SDG 4 is based on the generalization of free and equitable infant, primary and secondary education; quality technical, vocational and higher education; access to technical and professional skills to promote access to employment, decent work and entrepreneurship; the elimination of gender disparities and ensuring equal access for vulnerable people; guarantees of literacy for the majority of the population and the acquisition of basic notions of arithmetic. As means of implementation it is listed building and upgrading educational facilities, increasing scholarships worldwide and increasing the number of qualified teachers. In this work, target 4.7. has a determinant influence, that proposes

by 2030 , ensure that all learners acquire the knowledge and skills needed to promote sustainable development, including, among others, through education for sustainable development and sustainable lifestyles, human rights, gender equality, promotion of a culture of peace and nonviolence, global citizenship and appreciation of 
cultural diversity and of culture's contribution to sustainable development. (UN, 2015, p.17/35)

We have consumed more than a third of the time set for the fulfilment of the Sustainable Development Goals (SDGs). In September 2019, at the SDGs Summit, world leaders called for a decade of action and results for sustainable development, and pledged to mobilize financing, enhance national implementation and strengthen institutions to achieve the goals by the target date (UN, 2019). For this decade, they propose:

Global actions to ensure greater leadership, more resources and smarter solutions with respect to the SDG.

Actions at the local level addressing the necessary transitions in the policies, budgets, institutions and regulatory frameworks of governments, cities and local authorities.

Mobilization of people, including youth, civil society, media, private sector, trade unions, academia and other stakeholders in order to generate an unstoppable movement to drive the necessary transformations.

In the field of education, beyond the quantitative results that generate international comparative indicators (basic variables of the education and school systems, years of compulsory education, access to schooling, permanence, graduates and results), the challenge of (re)thinking about what education we need in order to tackle the major global challenges is formulated.

The answer is complex and cannot be articulated without fundamental analysis of the model of societies we want, the models of development we can afford and the concept of sustainability that underlies the discourses of the establishment.

\section{GLOBAL CITIZENSHIP EDUCATION (GCE)}

As stated in the 'GCE for Unknown Futures' report (Suša, 2019), during the last two decades a broad framework has been created regarding GCE, bringing together different perspectives, views and ideas. Undoubtedly, GCE and its different 'adjectives' and dimensions come to a large extent from the work carried out by international organisations (such as UNESCO and the North-South Centre of the Council of Europe) in a global framework, while by NGOs and public administrations in national and regional territories.
In recent decades, GCE's exact meaning and aim have been discussed (Hicks 2003; Peters, 2010; Suša, 2019), focusing on two key lines. The first line uses the development of GCE generally acceptable definitions at national, regional and global levels to develop frameworks for action as a reference point.

These processes have been largely driven by social bodies and administrations. Complex processes have been created, involving NGDO platforms, development agencies, Foreign Offices and Education Departments in some cases. The development of such processes has been heterogeneous, as some of them have come together in creating national strategies for GCE; some others have stagnated, while some are still active (Hartmeyer y Wegimont, 2016; GENE, 2017; Longueira, 2018; Suša, 2019).

The second environment has been established by international organisations with two coexisting models. In the European context, the North-South Centre of the Council of Europe boosted this in 2002, as the first GCE Congress was organised in Europe. A reference document was developed out of this Congress, the socalled 'Maastricht Global Education', leading to the Global Education concept. In a broader international context, UNESCO (2014) has had a key role due to the so-called Global Citizenship Education.

Both approaches have been criticised and opposed, especially due to the concept of "citizen' (in contrast to the 'non-citizens'), based on a model that grants rights and privileges only to some and not to others. As such, this is considered as an element that generates some status or type of recognised citizens, in opposition to those who are invisible and not recognised, and have fewer resources (Andreotti 2011; Mannion, Biesta, Priestley, \& Ross, 2011; Pashby, 2011; Suša, 2019).

In this sense, a line of academic papers has been developed, led by Vanessa Andreotti, where two different ways of understanding GCE and its related actions can be seen: soft vs. critical (Andreotti, 2006; Andreotti, Stein, Ahenakew \& Hunt, 2015). Each approach covers various possible perspectives, with a wide range of diversity and complexity. The soft approach does not consider the need for any amendment or change of course, as it is built on small modifications that keep the balance of the system as we know it. It is based on the assumption of universal and universally valid knowledge that heads for individual and institutional changes. These may be expensive or difficult to imple- 
ment, but they do not change the course of things or the dominant school of thought. The radical or critical approach is based on the need for not only changing the individual behaviour and institutions but also recognising epistemological dominance, to change the way of thinking and the construction of knowledge on which the system' is based. Within this critical approach, it is possible to go beyond reform and raise a critique of modernity from all sides that lead to systemic violence, challenging the foundations of our thinking, breaking current and socially rooted worldviews. It is a change in our way of being and understanding.

Both approaches lead to very different results in relation to the research methodologies, delivery of outcomes and building relationships and partnerships within the organised civil society.

\section{THE ROLE OF EUROPEAN CSO IN EXPANDING THE CONCEPT OF GCE}

Global citizenship education as it is understood today did not emerge from a whim but rather from a process of first, understanding, and then, incorporating a variety of views coming from different sectors of society, where CSOs have played a fundamental role in the European public sphere in the last decade. GENE, the DARE Forum of Concord, the North-South Centre of the Council of Europe, the Multi-Stakeholder Group on Development Education, among others, have relentlessly advocated for Global Education to critically engage with development policies.

European CSOs have been important actors in education for development in the last decades from the following perspectives (Krause, 2016),

a) CSOs from countries with a colonial background and a tradition of solidarity movements, and

b) CSOs from countries with a relatively recent political and economic transition where civil rights movements are at the forefront.

This difference is fundamental to understand the ways in which CSOs engage with global citizenship education at large. Actions and strategies will be influenced by the experiences coming from their own societies, and will therefore, establish different priorities for engagement.
If development education and, consequently, GCE, is about to make complex connections understandable and to enable people to act responsibly in a highly interdependent, globalized world (Troll \& Krause, 2016) how will this unfold in reality?

The Bridge 47 Project gathers different European CSO's perspectives and experiences from an associative, networking, innovative and knowledge creation framework. The goal is to promote a transformative change in society through the dialogue and joint work between scholars, professionals and policymakers.

\section{THE BRIDGE 47 PROJECT. GCE AS THE MAIN FOCUS IN EUROPE}

Bridge 47 , as a project following the way paved by previous DEEEP programs funded by DEAR EC, is about bringing together the two practices in development education identified by the report for DEAR, namely,

1. Campaigning for global justice and

\section{Global learning.}

Bridge 47 advocates for target 4.7 of the SDGs, which is related to education for social transformation, e.g. global citizenship education and education for sustainable development. In doing so, Bridge 47 offers learning and networking spaces for transformative learning experts and enthusiasts to connect, share their research and projects, inspiring people to act.

The Bridge 47-Building Global Citizenship mobilises global civil society to contribute to global justice and eradication of poverty through Global Citizenship Education (GCE).

The project focuses on joint advocacy efforts and building new partnerships, while it also supports civil society to develop new approaches to reaching out to new stakeholders, and provides tools to promote and act upon Global Citizenship in the context of SDG4.

The project works closely with partners engaged in informal and non-formal education, and life-long learning with a view to promoting transformative change in society. 
Figure 1. Bridge 47- Building Global Citizenship

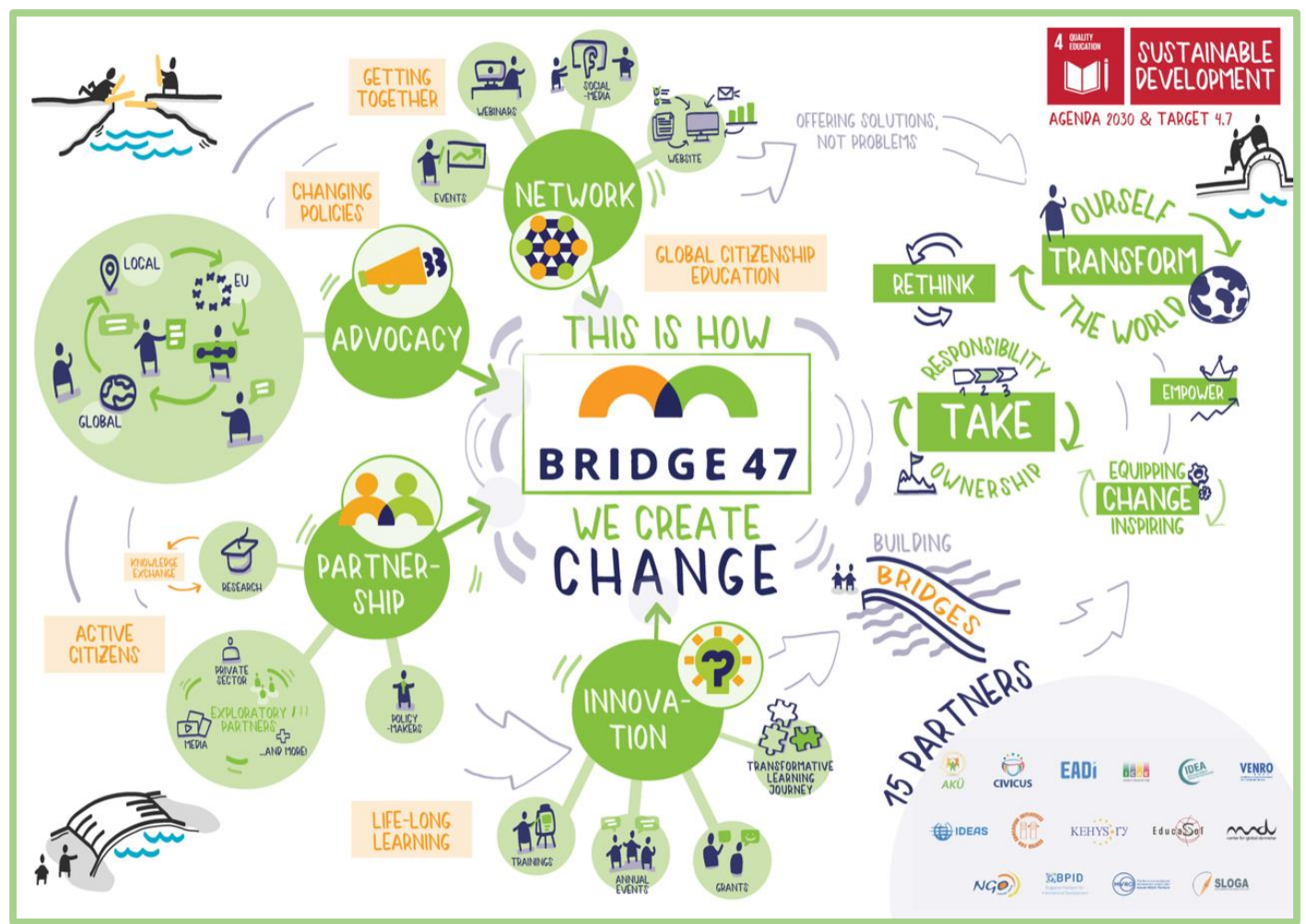

Note. Structure of a project. Reproduced from: https://www.bridge47.org/ .

\section{KNOWLEDGE EXCHANGE PARTNERSHIPS FOR BRIDGING CSOS AND HE}

As previously stated, the international organisations mentioned above, the CSO, and national and regional administrations have been crucial in building GCE reference framework. The academic world has participated in conceptual development, but its contribution is less compared to other areas of knowledge. This is why creating a space for dialogue that breaks the artificial limits created during the last two decades is a challenge for all GCE's stakeholders taking part in it.

The Bridge 47 Knowledge Exchange Partnerships bring together higher education and CSOs experts who work with transformative learning and education for active citizenship in Europe. These partnerships were started in 2018 , with the aim to facilitate the exchange of ideas of like-minded allies and motivate them to engage in opportunities for cooperation in the fields of GCE and ESD.

So far, the Bridge 47 Knowledge Exchange Partnerships have facilitated trans-European (and even beyond) connections and EADI and
Bridge 47 strive to form a coalition for education that inspires allies in Europe and beyond. What is unique about the Knowledge Exchange Partnerships is that these represent the first such space to facilitate higher education and CSOs experts' conversations and reflexivity in the broader 4.7 community in Europe.

EADI's work in Knowledge Exchange Partnerships is aimed to build bridges between national/regional development higher education and research organisations and national/regional civil society actors. It is important to build upon already existing approaches of collaboration to develop a common space for exchanging and sharing between research and practice, in accordance with the message developed by Bridge 47 reflected in the Target 4.7 Roadmap. The partners shall contribute from their different perspectives, from ideas to action, and from practical work to further research. Partnerships might lay the ground for the identification and fomulation of needs for future research and action/practice.

Within the timeframe of the project, the partnerships hosted expert events, on site and online, carried on networking and exchange, disseminated further on GCE in other platforms and collectives, and came together for specific activi- 
ties as workshops, webinars, publications, with the support of the larger Bridge 47 network.

\section{BRIDGE'S WORK METHODOLOGY}

This project uses social cartography as the main methodological approach to answer the followingquestions:

- What is the benefit of Global Citizenship Education to our societies?

- What is its impact?

- Why is Global Citizenship Education the answer to global challenges?

Social cartography aims to identify and record different debates and approaches within specific fields to offer more complex analyses that examine multiple perspectives or understandings of key concepts. In this case, the work is based on mapping different projects, partnerships and discourses related to GCE. Each initiative is later examined as a case study.

This method helps to outline different understandings of the reference field. After discourses and actions are outlined, then the focus is on revitalising current relationships and on developing new partnerships that seek to integrate the various possible contributions of different approaches without a need for resorting to large-scale consensus (or the lowest common denominator) as a basis for cooperation.

The process of building up partnerships for knowledge exchange in the Bridge 47 project has been one of learnings and challenges in the face of the shrinking of civil society spaces, the mainstreaming of populism, the widespread of fake news, and, lately, the COVID-19 pandemia.

EADI and Bridge 47 focused on re-invigorating existing spaces who had emerged in the European context through the work of CSOs in the last decade. An array of like-minded allies and experts working in GCE and development, in general, were open and willing to engage with the goals and spirit advocated by the Bridge 47 consortium. With resources in place, a series of activities could take place with the invaluable support of experts, academics, and civil society allies.

Among the organizations and institutions active in the Knowledge Partnerships in the last three years are MUNDU (Denmark), Ambrela (Slovakia), SLOGA (Slovenia), IDEAS Scotland,
Comenius University at Bratislava (Slovakia), the University of Stirling (Scotland), Fundación Etea (Spain), Liverpool World Centre (United Kingdom), Universidade de Santiago de Compostela (Spain), Sinergias ED (Portugal), GERIF (Finland), and the research network on education for sustainability in Denmark.

\section{CONCLUSIONS}

The Bridge has focused on creating three product categories: inputs for GCE work and progress of Target 4.7, the creation of collaborative networks and knowledge and advocacy.

The Bridge 47 Knowledge Exchange Partnerships are the basis for supporting a Massive Open Online Course (MOOC) to provide online learning on Global Citizenship in the context of SDG4, and for publishing a Knowledge Exchange Partnership publication to inspire those persons and organisations who want to set up their own knowledge partnerships in the future.

The project has generated proposals for monitoring Target 4.7. In particular, 3 papers have been published related to its measurement, progress and characteristics (Kunda \& Naughton, 2019a, byc).

EADI's main aim has been to bridge the work of researchers and practitioners, while disseminating and facilitating Global Citizenship exchanges, integrating the outcomes of the Bridge 47 Project among EADl's members and beyond through further activities towards ownership and replication of the Bridge 47 outputs.

During the winter 2020/2021 EADI will bring together a core group of allies at an online conference to debate on the encounters and disencounters between GCE and ESD, plus best practices for future cooperation between higher education and CSOs experts. The aim of the conference is to reflect and summarise on the processes and experiences of the Knowledge Partnerships during the duration of the Bridge 47 project and wrap up recommendations for research and action/practice.

Furthermore, a major effort has been made to provide suggestions that enable the junction between Target 4.7 in terms of transfomative education and the European Commission's political priorities between 2019 and 2024: The Green Deal, Future of Europe, Digital Education Plan, A Strong Social Europe for Just Transition, 
European Education Area and New European Consensus on Development.

To this effect, in 2019 Bridge brought together 200 education practitioners, academics, government representatives, civil servants and civil society organisations from around the world to create the 'Envision 4.7 Roadmap' (Bridge 47, 2020a), a collaborative policy road map to implement SDG Target 4.7 in Europe. As a result, there are six papers related to the following topics (Bridge 47, 2020b, c, d, e, f y g):

- Transformative education

- Cross-sectorial cooperation

- $\quad$ Indicators forSDG Target 4.7

- $\quad$ Life-longlearning

- $\quad$ Competencies for SDG Target 4.7

- $\quad$ Resources for SDG Target 4.7

Compliance with the SDGs is not possible without a real and conscious commitment to a concept of sustainability that takes into account its three dimensions: environmental, social and economic. The development of a new social, economic and consumption model affects and depends on education, and not only on general education, usually translated into compulsory school systems, but on broad and comprehendsive education systems that are articulated around critical paradigms and aimed to promote the transition to complex models of thinking, in accordance with the major challenges we face. The foundations of a transformative education from the radical perspective presented in the third section dedicated to Global Citizenship Education (GCE), generates new job opportunities, dialogue and the construction of alternatives

If we really want to "leave no one behind" (UN, 2015) we must accelerate decision-making towards a model that represents a radical change of direction in its evolution. In this process, education will have a detemining role, but we must not forget that education itself will need to favour profound intrinsic changes based on an educational design that favours the generation of capacities.

\section{REFERENCIAS BIBLIOGRÁFICAS}

- Andreotti, V. (2006). Soft versus critical global citizenship education. Policy and Practice: $A$ Development Education Review, 3, 40-51. https://www.developmenteducationreview.com/s ites/default/files/article-

pdfs/andreotti\%20focus\%204.pdf.

- Andreotti, V. (2011). The political economy of global citizenship education. Globalisation, Societies and Education, 9(3-4),307-310. DOI: https://doi.org/10.1080/14767724.2011.602292.

- Andreotti, V., Stein, S., Ahenakew, C., \& Hunt, D. (2015). Mapping interpretations of decolonization in the context of higher education. Decolonization: Indigeneity, Education \& Society, 4(1), 21-40. https://jps.library.utoronto.ca/index.php/des/arti cle/view/22168/18470.

- Bridge 47 (2020a). Envision 4.7: Roadmap in Support of SDG Target 4.7.

https://www.bridge47.org/sites/default/fil es/202 0-01/envision_4.7_roadmap_0.pdf.

- Bridge 47 (2020b). Envision 4.7 Policy Paper: Transformative Education.

https://www.bridge47.org/sites/default/fil es/202 0-09/bridge47_policy_paper-

_transformative_education_v1_190820_5.pdf.

- Bridge 47 (2020c). Envision 4.7 Policy Paper: Cross-sectoral Cooperation.

https://www.bridge47.org/sites/default/fil es/202 0 -

09/bridge47_policy_paper_cross_sectoral_cooperat ion_v2_190820_4.pdf.

- Bridge 47 (2020d). Envision 4.7 Policy Paper: Indicators for SDG Target 4.7.

https://www.bridge47.org/sites/default/fil es/202 0 -

09/bridge47_policy_paper_indic ators_for_sdg_targ et_4.7_v1_190820_4.pdf.

- Bridge 47 (2020e). Envision 4.7 Policy Paper:

Lifelong Learning.

https://www.bridge47.org/sites/default/fil es/202 0 -

09/bridge47_policy_paper_lifelo ng_learning_v1_19 0820_4.pdf.

- Bridge 47 (2020f). Envision 4.7 Policy Paper: Competencies for SDG Target 4.7.

https://www.bridge47.org/sites/default/fil es/202 0 -

09/bridge47_policy_paper_compet encies_for_sdg_t arget_4.7_v1_190820_4.pdf.

- Bridge 47 (2020g). Envision 4.7 Policy Paper: Resources for SDG Target 4.7.

https://www.bridge47.org/sites/default/fil es/202 0 -

09/bridge47_policy_paper_resources_for_sdg_targe t_4.7_v1_190820_4.pdf

- Council of Europe (2002). European Strategy Framework For Improving and Increasing Global Education in Europe to the Year 2015. The

"Maastricht Global Education Declaration". Europe- 
wide Global Education Congress.

https://rm.coe.int/168070e540.

- GENE (2017). The State of Global Education in Europe 2017. https://gene.eu/wpcontent/uploads/State-of-Global-Education-2017low-res.pdf.

- Hartmeyer, H., \& Wegimont, L. (Eds.). (2016). Global Education in Europe Revisited: Strategies and Structures. Policy, Practice and Challenges. Waxmann Verlag.

- Hicks, D. (2003). Thirty years of global education: A reminder of key principles and precedents. Educational review, 55(3), 265-275. DOI: https://doi.org/10.1080/0013191032000118929.

- Krause, J. (2010). DEAR in Europe. Recommendations for Future Interventions by the European Commission. Final Report of the 'Study on the Experience and Actions for the Main European Actors Active in the Field of Development Education and Awareness Raising". European Commission, Development Education and Awareness Raising. https://gene.eu/wpcontent/uploads/Gene_OtherPublic ationsDEWatchReport.pdf.

- Krause, J. (2016). NGOs in Global Education: From Promoting Aid towards Global Citizen Empowerment for Change. In H. Hartemeyer, \& L. Wegimont (Eds), Global Education in Europe Revisited: Strategies and Structures, Policy, Practice and Challenges (pp. 149-159). Waxmann. http://waxmann.ciando.com/img/books /extract/3 830985274_lp.pdf.

- Kunda Marron, R. \& Naughton, D. (2019a). Using Learning Assessment Data to Monitor Progress for SDG Target 4.7. Bridge 47 Network. https://www.bridge47.org/sites/default/fil es/201 9-11/using_learning_assesment_data_2.pdf.

- Kunda Marron, R. \& Naughton, D. (2019b). Monitoring Progress Towards SDG Target 4.7 in Europe: Proposed Framework and Tools. Bridge 47 Network.

https://www.bridge47.org/sites/default/fil es/201 9-11/monitoring_progress_to_4.7_2.pdf.

- Kunda Marron, R. \& Naughton, D. (2019c). Characteristics of Target 4.7 and The Importance of its Inclusion to the Sustainable Development Goals. Bridge 47 Network.

https://www.bridge47.org/sites/default/fil es/201 9-11/characteristics_of_4.7_1.pdf.

- Longueira, S. (2018). Introducción a la Educación para el Desarrollo, conceptos y evolución histórica. En, R. de Palma, La educación para el desarrollo y la ciudadanía global (pp. 15-32). Graó.

- Mannion, G., Biesta, G., Priestley, M., \& Ross, H. (2011). The global dimension in education and education for global citizenship: Genealogy and critique. Globalisation, Societies and Education,
9(3-4), 443-456. DOI:

https://doi.org/10.1080/14767724.2011.605327.

- Pashby, K. (2011). Cultivating global citizens: Planting new seeds or pruning the perennials? Looking for the citizen-subject in global citizenship education theory. Globalisation, Societies and Education, 9(3-4), 427-442.

https://doi.org/10.1080/14767724.2011.605326.

- Peters, M.A. (2010). Global Citizenship Education: politics, problems and prospects. Citizenship, Social and Economics Education, 9(1), 43-47. DOI: http://dx.doi.org/10.2304/csee.2010.9.1.43.

- Suša, R. (2019). Global Citizenship Education (GCE) for Unknown Futures. Mapping Past and Current Experiments and Debates. Bridge 47 project. https://www.bridge47.org/sites/default/fil es/201 9-07/bridge47_gce_for_unknown_futures_reportcompressed_0.pdf.

- Troll, T., \& Krause, J. (2016). The Future of Development Education: Transformational learning for a world citizens movement. In A. Skinner, M. Ballie Smith, E. Brown, \& T. Troll (Eds.), Education, Learning and the Transformation of Development (pp. 143-157). Taylor \& Francis.

- UN (2015). A/RES/70/1. Transforming our world: the 2030 Agenda for Sustainable Development https://www.un.org/ga/search/view_doc.asp?sym $\mathrm{bol}=\mathrm{A} / \mathrm{RES} / 70 / 1 \&$ Lang $=\mathrm{E}$.

- UNESCO (2014). Global Citizenship Education: Preparing Learners for the Challenges of the 21st Century. UNESCO.

https://unesdoc.unesco.org/ark:/48223/pf000022 7729. 